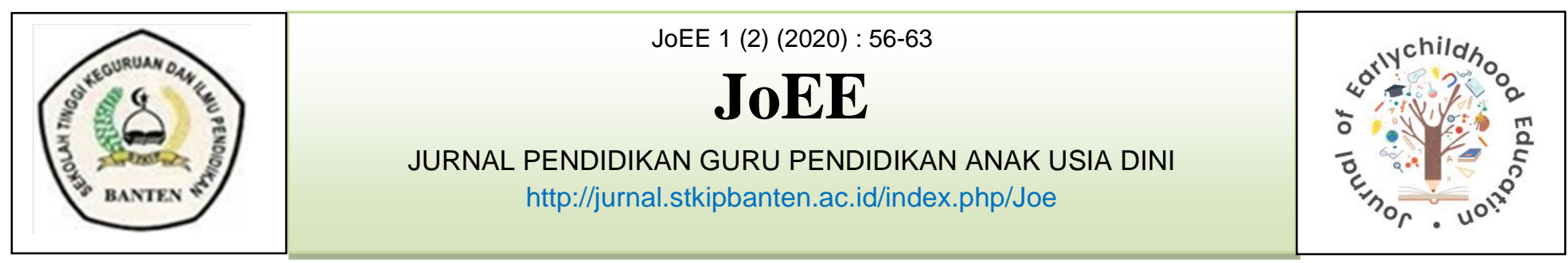

\title{
PENGGUNAAN MEDIA KERTAS LIPAT MELALUI KEGIATAN BERMAIN UNTUK MENINGKATKAN MOTORIK HALUS ANAK USIA DINI
}

\author{
Alvan Hazhari \\ hazharialvan@gmail.com \\ Pendidikan Guru Pendidikan Anak Usia Dini \\ Sekolah Tinggi Keguruan Dan Ilmu Pendidikan Banten
}

\begin{abstract}
Abstrak
Bermain sangat penting bagi anak usia dini karena melalaui bermain dapat meningkatkan aspek-aspek perkembangan, salah satunya aspek perkembangan motorik halus dengan menggunakn media kertas lipat. Tujuan penelitian ini adalah adalah untuk mengetahui peningkatan motorik halus melalui kegiatan bermain dengan media kertas lipat pada anak usia dini. Peneltian ini adalah penelitian kepustakaan (Library Research), Pengumpulan data peneliti menggunakan paper dan journal ilmiah, tesis dan disertasi, skripsi, dan dokumentasi. Rata-rata hasil pretes sebelum menggunakam model pembelajaran media lipat kertas yaitu 33,02\%dan sesudah menggunakan media lipat kertas meningkat menjadi $64,43 \%$ dengan rata-rata peningkatan $31,41 \%$. Adapun kesimpulan dari penelitian ini adalah trdapat peningkatan motorik halus pada anak uisa dini dengan menggunakan media kertas lipat.
\end{abstract}

Kata kunci: Bermain, Media Kertas Lipat, Motorik Halus.

\section{Pendahuluan}

Dunia anak adalah dunia bermain, melalui bermain anak memperoleh pelajaran yang mengandung aspek perkembangan kognitif, sosial, emosi, dan perkembangan fisik. Halserupa menurut Mutiah (2010:91) mengatakan bahwa Kegiatan yang sangat penting bagi pertumbuhan dan perkembangan anak adalah bermain, bermain harus dilakukan atas inisiatif anak dan atas keputusan anak itu sendiri. Bermain harus dilakukan dengan rasa senang, sehingga semua kegiatan bermain yang akan menghasilkan proses belajar pada anak.
Bermain sangat penting bagi anak usia dini karena melalaui bermain dapat meningkatkan aspek-aspek perkembangan seperti aspek fisik, sosial, emosional, dan kognitif. Kegiatan dalam bermain mengembangkan aspek fisik dan motorik anak yaitu melalui permainan motorik kasar dan halus, kemampuan mengontrol anggota tubuh, belajar keseimbangan, kelincahan, koordinasi mata dan tangan. Adapun dampak jika anak tumbuhh dan berkembang dengan fisik motorik yang baik maka anak akan lebih percaya diri, memiliki rasa nyaman, dan memiliki konsep diri yang positif. 
Berdasarkan pengamatan kondisi perkembangan anak di TK Al-Muhajirin pada kelompok B2, dalam pembelajaran diketahui adanya kendala pada kegiatan perkembangan fisik motorik halus ada beberapa anak yang tidak mau melanjutkan dengan alasan susah, dan hampir semua anak-anak yang belum bisa melipat dengan rapi sesuai dengan garis pada kertas lipat.

Pada saat anak dibimbing langkah-langkah melipat sesuatu tentang pembelajaran hari itu, hampir semua anak-anak meminta bantuan kepada gurunya. Hal tersebut menjadi kendala bagi guru untuk mengatasi anakanak yang belum bisa menirukan lipatan sesuai langkah-langkah yang diberikan oleh guru di depan kelas dalam melipat dari awal sampai akhir. Begitu pula menjadi kendala bagi anak-anak, dalam satu kelas hanya ada 1 guru sedangkan anak-anak banyak yang meminta bantuan, sehingga mereka tidak bisa maksimal dalam melaksanakan pembelajaran.

Dari 15 anak yang terdiri dari 7 putra dan 8 putri, yang dapat melakukan melipat sesuai dengan standart indikator pengembangan meniru lipatan bentuk 1-6 lipatan hanya beberapa anak. Pada anak kelompok B2 sebagian besar belum bisa menyelesaikan sampai tahap akhir, baru 1-3 lipatan anak-anak sudah meminta bantuan kepada guru dan juga sebagian besar belum bisa melipat dengan rapi sesuai garis pada kertas lipat. Hal tersebut kemampuan fisik motorik halus pada anak belum berkembang dan terampil dalam melipat kertas lipat.

Perkembangan motorik halus melibatkan otot-otot halus yang mengendalikan tangan dan kaki. Terkait dengan anak kecil, anda sebaiknya memberikan perhatian lebih kepada kontrol, koordinasi, dan ketangkasan dalam menggunakan tangan dan jemari. Meskipun perkembangan ini berlangsung serentak dengan perkembangan motorik kasar, otot-otot dekat batang tubuh matang sebelum otot-otot kaki dan tangan, yang mengendalikan pergelangan dan tangan. Jadi, penting bagi anak kecil untuk berlatih menggunakan otot-otot besar saat terlibat dalam kegiatan motorik halus. Penundaan pengembangan koordinasi motorik kasar mungkin berdampak negatif pada perkembangan kemampuan motorik halus. Tetapi begitu anak-anak bisa melakukan gerakan motorik halus, guru prasekolah sebaiknya mendorong mereka terlibat dalam semua jenis kegitan manipulatif sehingga mereka bisa belajar dan lalu menerapkan kemampuan yang diperlukan untuk menggunakan tangan jemari dengan control dan tangkas (Beaty, 2013:236).

$$
\text { Uraian diatas merupakan }
$$

sebagian besar gambaran yang perlu diteliti kebenarannya sehingga mendapatkan perubahan yang lebih baik, dan dapat dijadikan sebagai bahan pertimbangan lebih lanjut dalam pembahasan peningkatan fisik motorik halus melalui kegiatan bermain dengan media kertas lipat.

Dari pembahasan diatas maka peneliti perlu mengadakan penelitian tentang Penggunaan Media Kertas Lipat Melalui Kegiatan Bermain Untuk Meningkatkan Motorik Halus Anak Usia Dini. Adapun rumusan masalah yang akan diteliti yaitu sebagai berikut: Apakah melalui kegiatan bermain dengan media kertas lipat dapat meningkatkan fisik motorik halus pada anak kelompok B2 di TK Al-Muhajirin Kecamatan Tunjungteja. Dengan tujuan penelitian ini adalah untuk mengetahui peningkatan motorik halus melalui kegiatan bermain dengan media kertas lipat pada anak usia dini.

Origami adalah seni melipat kertas, yang terkenal berasal dari dan berkembang di Jepang. Sebagai hobi origami memang terlihat sepele, tapi jika dilihat sebagai sesuatu yang mendidik, origami akan bermakna sangat besar. Ada berbagai macam manfaat yang diperoleh dari seni lipat-melipat ini 
(Simpleepaper.blogspot.co.id/2012 diaskes pada tanggal 29 Februari 2020).

Menurut kamus Webster's Third New International (seperti yang dikutip Isao Honda, 1965) origami merupakan seni melipat kertas dari Jepang atau sesuatu (menampilkan bentuk dari burung, serangga, dan bunga) yang dihasilkan dari seni melipat kertas (Elib.unikom.ac.id diaskes pada tanggal 23 Maret 2020).

Aktivitas bermain merupakan suatu rangkaian kegiatan pembelajaran. Kegiatan yang dilakukan membutuhkan pengaturan lingkungan bermain dan belajar serta alatalat permainan yang dibutuhkan (Risaldy, 2014:45). Bermain merupakan prinsip dasar anak usia dini, sehingga wajar apabila bermain menjadi salah satu metode yang wajib dilakukan guru dalam pembelajaran anak usia dini (Risaldy, 2014:32). Plato, Aristoteles, dan Frobel (Mutiah, 2010:93) menganggap bermain sebagai kegiatan yang mempunyai nilai praktis. Artinya bermain digunakan sebagai media untuk meningkatkan keterampilan dan kemampuan tertentu pada anak.

Jadi dapat disimpulkan bahwa Bermain merupakan suatu kegiatan pembelajaran yang menyenangkan tanpa ada paksaan atau tekanan dan tidak mempunyai peraturan dalam permainan, kegiatan yang dilakukan membutuhkan peraturan lingkungan bermain dan belajar serta alat-alat permainan yang dibutuhkan menggunakan anggota seluruh anggota tubuh, dan kegiatan bermain digunakan sebagai alat untuk meningkatkan keterampilan dan kemampuan tertentu pada anak. Pengembangan fisik adalah pertumbuhan dan perubahan yang terjadi pada tubuh/badan/ jasmani seseorang (Hildayani, 2014:8.3).

Motorik halus adalah gerakan yang menggunakan otot-otot halus atau sebagian anggota tubuh tertentu yang dipengaruhi oleh kesempatan untuk belajar dan berlatih (Hasnida, 2014:52).
Keterampilan motorik halus adalah aktivitas-aktivitas yang memerlukan pemakaian otot-otot kecil pada tangan. Aktifitas ini termasuk memegang benda kecil seperti manik-manik, butiran kalung, memegang sendok, memegang pensil dengan benar, menggunting, melipat kertas, mengikat tali sepatu, mengancing dan menarik ritsleting. Aktivitas tersebut terlihat mudah namun memerlukan latihan dan bimbingan agar anak dapat melakukannya secara baik dan benar (Damay, 2012:52) sehinggga Fisik motorik halus merupakan perubahan yang terjadi pada tubuh seseorang dengan kemampuan untuk menggerakkan otot-otot kecil atau halus pada bagian tangan dengan menggunakan media sebagai alat $b$ antu untuk melatih koordinasi mata dan tangan.

\section{Metode}

Penelitian ini menggunakan penelitan kepustakaan (Library Research), yaitu serangkaian penelitian yang berkenaan dengan metode pengumpulan data pustaka, atau penelitian yang obyek penelitiannya digali melalui beragam informasi kepustakaan (buku, ensiklopedi, jurnal ilmiah, koran, majalah, dan dokumen) Nana Syaodih (2010:52).

Penelitian kepustakaan atau kajian literatur (literature review, literature research) merupakan penelitian yang mengkaji atau meninjau secara kritis pengetahuan, gagasan, atau temuan yang terdapat didalam tubuh literatur berorientasi akademik (academic-oriented literature), serta merumuskan kontribusi teoritis dan metodologisnya untuk topik tertentu. Cooper dan Taylor dalam Mohammad Imam Farisi. (2010:105). Fokus penelitian kepustakaan adalah menemukan berbagai teori, hukum, dalil, prinsip, atau gagasan yang digunakan untuk menganalisis dan memecahkan pertanyaan penelitian yang dirumuskan Adapun Teknik Pengumpulan data dari pennelitian ini, Data yang digunakan dalam penelitian ini adalah data sekunder. Data sekunder merupakan data yang 
diperoleh bukan dari pengamatan langsung. Akan tetapi data tersebut diperoleh dari hasil penelitian yang telah dilakukan oleh peneliti-peneliti terdahulu.

Sumber utama penelitian ini adalah jurnal yang ditulis oleh Rizda Melasanti Peningkatan Fisik Motorik Halus Melalui Kegitan Bermain Dengan Media Kertas Lipat Pada Anak Kelompok A2 Di Ra AlAmin 02 Salatiga tahun Pelajaran 2017/2018. Jurnal tersebut diterbitkan oleh IAIN Salatiga pada tahun 2018. Jurnal tersebut dipilih oleh penulis berdasarkan beberapa pertimbangan. Pertama, relevansi jurnal dengan rumusan masalah pada penelitian ini. Kedua, tingkat keabsahannya dapat diprtanggungjawabkan. Dalam jurnal tersebut, Rizda Melasanti memaparkan alasan pentingnya memunculkan penggunaan media kertas lipat dalam aktivitas kelas, inspirasi yang menyebabkan mereka akhirnya melakukan penelitian tersebut, serta data hasil dari penelitian yang dilakukannya. Menurut Rizda Melasanti, penelitiannya penting dilakukan guna mencertitakan peningkatan motoric halus pada AUD dengan menggunakan metode kertas lipat serta dapat dijadikan sebagai salah satu inspirasi dalam menciptakan suatu strategi pembelajaran.

Analisis data merupakan upaya mencari dan menata secara sistematis data yang telah terkumpul untuk meningkatkan pemahaman penelitian tentang kasus yang diteliti dan mengkajinya sebagai temuan bagi orang lain. Noeng Mohadjir (2013: 28).

Analisis data yang digunakan dalam penelitian ini adalah analisis anotasi bibliografi (Annotated bibliography). Anotasi berarti suatu kesimpulan sederhana dari suatu artikel, buku, jurnal, atau beberapa sumber tulisan yang lain, sedangkan bibliografi diartikan sebagai suatu daftar sumber dari suatu topik. 132The UCSC University Library. Write a Literature Review (http://guides.library.ucsc.edu/write-a- literature-review diakses tanggal 10 Mei 2020).

Analisis Data Terdapat tiga hal yang harus diperhatikan dalam suatu analisis anotasi bibliografi. Ketiga hal tersebut adalah: (1) Identitas sumber yang dirujuk; (2) Kualifikasi dan tujuan penulis; (3) Simpulan sederhana mengenai konten tulisan; dan (4) Kegunaan/pentingnya sumber yang dirujuk dalam menjawab permasalahan yang telah dirumuskan.

\section{Hasil dan Pembahasan}

Penelitian dengan penggunaan media kertas lipat melalui kegiatan bermaian untuk meningkatkan motorik halus pada Anak Usia dini ini menggunakan metode literatur. Jenis penelitian ini adalah penelitan kepustakaan (Library Research), penelitian kepustakaan yaitu serangkaian penelitian yang berkenaan dengan metode pengumpulan data pustaka, atau penelitian yang obyek penelitiannya digali melalui beragam informasi kepustakaan baik itu buku, ensiklopedi, jurnal ilmiah, koran, majalah, dan dokumen-dokumen lainnya yang berhubungan dengan media kertas lipat. (Nana Saodah 2017:42)

Identitas objek sumber yang dirujuk:

$$
\text { Data A.1. Skripsi: Ajeng }
$$

Marselyna (2010) Judul, Meningkatkan Motorik Halus Anak Usia Dini Melalui Seni melipat Kertas Di Paud Tunas Asa Kemilang Bandar Lampung. A.2 Jurnal: Kiki Ria Mayasari (2014) Judul, Meningkatkan Keterampilan Motorik halus Melalui Kegiatan Melipat Kertas Pada Kelompok B4 di TK Masjid Syuhada Yogyakarta. Data A.3. Jurnal: Ni Kadek Seru Ayu Wiryaningsih, I Nyoman Jampel, Putu Aditya Antara (2016) Judul, Penerapan Kegiatan Melipat Kertas Origami Untuk Meningkatkan Kemampuan Motorik Halus Anak TK Aisyiyah Bustanul Athfal.

Analisis identitas sumber yang dirujuk.

Data ini berdasarkan rangkuman intisari dari hasil penelitian-penelitian 
yang terkait dengan penelitian terdahulu yang terkait dengan Penggunaan media kertas lipat melalui kegiatan bermain untuk meningkatkan motorik halus anak usia dini. Data tersebut diambil dan dilaporkan kembali dengan cara deskriptif kualitatif dan kuantitatif. Kode data A1 skor pretes menunjukan data dari $26 \%$ menjadi $34 \% \%$ sehingga peningkatannya $8 \%$. Kode data A2 menunjukan dari $23,5 \%$ menjadi $76,4 \%$ dengan peningkatan mencapai $52,9 \%$. Kode data A3 dari $49,58 \%$ menjadi $82,91 \%$ dengan peningkatan mencapai $25,14 \%$. Rata-rata hasil pencapaian dari ketiga judul yang dianalisis sebelum menggunakam model pembelajaran media lipat kertas yaitu 33, $02 \%$ dan sesudah menggunakan media lipat kertas meningkat menjadi $64,43 \%$ dengan rata-rata peningkatan $31,41 \%$.

Kualifikasi dan Tujuan Penulisan

Kualifikasi: Kode Data A1 (PG PAUD), Kode Data A2 (PG TK), Kode Data A3 (PG PAUD).

Tujuan Penulisan Data A1, Tujuan Penelitian ini adalah untuk mengetahui Apakah dengan seni melipat kertas dapat meningkatkan motorik halus anak di Paud Tunas Asa Kemiling Bandar Lampung. Data A2, Tujuan yang ingin dicapai dalam penelitian ini adalah untuk meningkatkan keterampilan motorik halus melalui kegiatan melipat kertas pada kelompok B4 di TK Masjid Syuhada Yogyakarta. Kode Data A3, Tujuan yang ingin dicapai dalam penelitian ini adalah untuk meningkatkan keterampilan motorik halus melalui kegiatan melipat kertas Origami.

Simpulan Hasil Analisis dari Rujukan

Adapun simpulan hasil analisis dari identitas sumber yang dirujuk dalam jurnal dan skripsi dapat dilihat pada tabel berikut ini:

Tabel 4.5.

Daftar Jurnal dan Skripsi Penggunaan media kertas lipat melalui kegiatan bermain untuk meningkatkan motorik halus anak usia dini.

\begin{tabular}{|c|c|c|c|c|c|}
\hline $\begin{array}{l}\text { K } \\
\mathbf{o} \\
\mathbf{d} \\
\mathbf{e}\end{array}$ & $\begin{array}{c}\text { Varib } \\
\text { el } \\
\text { Terk } \\
\text { ait }\end{array}$ & $\begin{array}{c}\text { Metode } \\
\text { Peneliti } \\
\text { an }\end{array}$ & $\begin{array}{c}\text { Jmlh } \\
\text { Sampel }\end{array}$ & Hasil & $\begin{array}{c}\mathrm{Ke} \\
\mathbf{t}\end{array}$ \\
\hline $\begin{array}{c}\mathrm{A} \\
1\end{array}$ & $\begin{array}{c}\text { Meni } \\
\text { ngkat } \\
\text { kan } \\
\text { Motor } \\
\text { ik }\end{array}$ & $\begin{array}{l}\text { Peneliti } \\
\text { an } \\
\text { Tindak } \\
\text { an } \\
\text { Kelas } \\
\text { (PTK) }\end{array}$ & 15 & $\begin{array}{l}\text { skor } \\
\text { pretes } \\
\text { menunj } \\
\text { ukan } \\
\text { data } \\
\text { dari } \\
26 \% \\
\text { menjadi } \\
34 \% \% \\
\text { sehingg } \\
\text { a } \\
\text { peningk } \\
\text { atannya } \\
8 \% \text {. }\end{array}$ & $\begin{array}{l}\mathrm{Te} \\
\text { rja } \\
\text { di } \\
\mathrm{Pe} \\
\text { nin } \\
\text { gk } \\
\text { ata } \\
\mathrm{n}\end{array}$ \\
\hline $\begin{array}{c}\mathrm{A} \\
2\end{array}$ & $\begin{array}{c}\text { Meni } \\
\text { ngkat } \\
\text { kan } \\
\text { Keter } \\
\text { apilan } \\
\text { Motor } \\
\text { ik }\end{array}$ & $\begin{array}{c}\text { Peneliti } \\
\text { an } \\
\text { Tindak } \\
\text { an } \\
\text { Kelas } \\
\text { (PTK) }\end{array}$ & 17 & $\begin{array}{l}\text { Skor } \\
\text { Pre test } \\
\text { menunj } \\
\text { ukan } \\
\text { dari } \\
23,5 \% \\
\text { menjadi } \\
76,4 \% \\
\text { dengan } \\
\text { peningk } \\
\text { atan } \\
\text { mencap } \\
\text { ai } \\
52,9 \%\end{array}$ & $\begin{array}{l}\mathrm{Te} \\
\text { rja } \\
\text { di } \\
\mathrm{Pe} \\
\text { nin } \\
\mathrm{gk} \\
\text { ata } \\
\mathrm{n}\end{array}$ \\
\hline $\begin{array}{c}\text { A } \\
3\end{array}$ & $\begin{array}{c}\text { Meni } \\
\text { ngkat } \\
\text { kan } \\
\text { Kema } \\
\text { mpau } \\
\text { n } \\
\text { Motor } \\
\text { ik }\end{array}$ & $\begin{array}{l}\text { Peneliti } \\
\text { an } \\
\text { Tindak } \\
\text { an } \\
\text { Kelas } \\
\text { (PTK) }\end{array}$ & 20 & $\begin{array}{l}\text { dari } \\
49,58 \% \\
\text { menjadi } \\
82,91 \% \\
\text { dengan } \\
\text { peningk } \\
\text { atan } \\
\text { mencap } \\
\text { ai } \\
25,14 \%\end{array}$ & $\begin{array}{l}\text { Te } \\
\text { rja } \\
\text { di } \\
\text { Pe } \\
\text { nin } \\
\text { gk } \\
\text { ata } \\
\text { n }\end{array}$ \\
\hline
\end{tabular}

Dari tabel diatas menunjukan bahwa variabel dalam penelitian ini rata-rata untuk meningkatkan kemapuan motorik halus pada anak usia dini. Adapun hasil skor dari skripsi Ajeng Marselyna (2010) dan judul Meningkatkan Motorik Halus 
Anak Usia Dini Melalui Seni melipat Kertas di Paud Tunas Asa Kemilang Bandar Lampung, yaitu menunjukkan data dari $26 \%$ menjadi $34 \% \%$ sehingga peningkatannya $8 \%$. Jadi, dapat disimpulkan bahwa penggunaan media kertas lipat melalui kegiatan bermain untuk meningkatkan motorik halus anak usia dini meningkat dengan signifikan. Selanjutnya hasil skor Jurnal Kiki Ria Mayasari (2014) dan Judul Meningkatkan Keterampilan Motorik halus Melalui Kegiatan Melipat Kertas Pada Kelompok B4 di TK Masjid Syuhada Yogyakarta, yaitu menunjukkan bahwa Skor Pre test dari $23,5 \%$ menjadi $76,4 \%$ dengan peningkatan mencapai 52,9\%.

Dapat disimpulkan bahwa penggunaan media kertas lipat melalui kegiatan bermain dapat meningkatkan keterampilan motorik halus anak usia dini meningkat dengan signifikan. Berikutnya Jurnal $\mathrm{Ni}$ Kadek Seru Ayu Wiryaningsih, I Nyoman Jampel, Putu Aditya Antara (2016) dan Judul Penerapan Kegiatan Melipat Kertas Origami Untuk Meningkatkan Kemampuan Motorik Halus Anak TK Aisyiyah Bustanul Athfal. yaitu menunjukkan bahwa dari 49,58\% menjadi $82,91 \%$ dengan peningkatan mencapai 25,14\%.. Jadi, dapat disimpulkan bahwa Kegiatan Melipat Kertas origami dapat meningkatkan keterampilan motorik halus anak usia dini meningkat dengan signifikan.

Hasil Penelitian A1 menunjukkan bahwa peningkatan kemampuan anak yang kontinue dari setiap pertemuan di siklus I dan siklus II yang dihadiri oleh 15 anak (100\%). Pada siklus I dari 15 peserta didik yang menunjukkan Berkembang sangat Baik (BSB) pada pertemuan ke-1 sebesar $14 \%$, dan pada pertemuan ke-2 sebesar $20 \%$, Berkembang Sesuai Harapan (BSH) pada pertemuan ke-1 sebesar $6 \%$ dan pada pertemuan ke-2 sebesar $14 \%$ Yang Mulai Berkembang (MB) pada pertemuan ke-1 sebesar $20 \%$, dan pada pertemuan ke-2 sebesar 26\%, dan yang Belum Berkembang (BB) pada pertemuan ke-1 sebesar $60 \%$, dan pada pertemuan ke- 2 sebesar 40\%. Pada siklus II pun mengalami peningkatan yang sangat baik, dari 15 peserta didik yang menunjukkan Berkembang sangat Baik (BSB) pada pertemuan ke-1 sebesar $26 \%$, dan pada pertemuan ke-2 sebesar 34\%,Berkembang Sesuai Harapan (BSH ) pada pertemuan-1 sebesar $20 \%$ dan pada pertemuan-2 sebesar 26\%, Mulai Berkembang (MB) pada pertemuan ke-1 sebesar $34 \%$, dan pada pertemuan ke-2 sebesar $34 \%$, dan Belum Berkembang (BB) pada pertemuan ke-1 sebesar $20 \%$, dan pada pertemuan ke2 sebesar $6 \%$.

Hasil Penelitian A2 menunjukkan bahwa keterampilan motorik halus pada kelompok B4 sebelum tindakan yang dilakukan melalui observasi memperoleh data anak yang terampil sebanyak 5.9\%, pada siklus 1 sebanyak $23.5 \%$, pada siklus 2 sebanyak 76.4\%.Perolehan persentase pada siklus 2 membuktikkan bahwa penelitin ini telah mencapai indikator keberhasilan yaitu $=75 \%$ keterampilan motorik halus anak kelompok B4 mengalami peningkatan. Berdasarkan hasil penelitian ini dapat disimpulkan bahwa melalui kegiatan melipat kertas dapat meningkatkan keterampilan motorik halus pada Kelompok B4 di TK masjid Syuhada Yogyakarta.

Hasil Penelitian A3 menunjukkan bahwa kemampuan motorik halus anak rendah, hal ini dapat dilihat dari adanya peningkatan rata-rata kemampuan motorik halus anak pada siklus I adalah 49,58\% yang berada pada kategori sedang dan ratarata peningkatan kemampuan motorik halus anak pada siklus II sebesar $82,91 \%$ berada pada kategori tinggi. Ini menunjukkan adanya peningkatan presentase kemampuan motorik halus anak dari siklus I ke siklus II sebesar 33,33\%.

Jadi dapat disimpulkan dari ketiga judul hasil analisis saya menunjukkan hasil yang signifikan karena semuanya menunjukkan peningkatan sehingga dengan menggunakan media melipat kertas 
origami dapat meningkatkan kemampuan motorik halus pada anak usia dini

Kegunaan sumber yang dirujuk dalam menjawab permasalahan.

Pembelajaran menggunkan media merupakan sangat penting bagi anak usia dini untuk mengembangkan fisik motorik sebagai pengembangan kemampuan dasar anak usia dini. Kegiatan pengembangan fisik motorik mencakup kegiatan yang mengarah pada kegiatan untuk melatih motorik kasar dan halus yang terdiri atas gerakan-gerakan jalan, lari, lompat, senam, keterampilan dengan bola, ketrampilan menggunakan peralatan, menari, latihan ritmik dan gerakan berkordinasi termasuk pembelajaran mengguakan media kertas lipat. Dimana media melipat kertas merupakan salah satu kegiatan yang bertujuan untuk melatih koordinasi mata dan otot-otot tangan serta konsentrasi. (Sumantri 2005:46)

Disamping itu pula kegiatan melipat kertas menjadikan anak usia dini berpengaruh terhadap kesiapan anak dalam menulis (pengembangan bahasa), kegiatan melatihkan koordinasi antara tangan dengan mata yang dianjurkan dalam jumlah waktu yang cukup meskipuns penggunaan tangan secara utuh belum mungkin tercapai. Kemampuan daya lihat juga merupakan kegiatan motorik halus lainnya, melatih kemampuan anak melihat ke arah kiri dan kanan, atas bawah yang penting untuk persiapan membaca awal. Hasil analisis yang dicapai dari media kertas lipat berhasil karena meningkatkan motorik halus anak usia dini.

Adapun hasil temuan-temuan yang didapatkan dari meode pembelajaran dengan menggunakan metode media kertas lipat antara lain Pertama, Melalui media pembelajaran metode media kertas lipat siswa akan menjadi gerak secara aktif di ruangan sehingga motorik halus akan berkembang dengan baik. Jari-jari anak akan terampil dalam melakukan berbagai gerakan melipat dan ini akan meningkatkan kognitif pada anak. Kedua Melalui media pembelajaran metode media kertas lipat siswa dapat memperoleh pengalaman belajar yang menyenangkan dan mudah dipahami. Ketiga, Melalui media pembelajaran metode media kertas lipat suasana ruang kelas menjadi riang gembira tidak menjadikanya suasana tegang terhadap siswa. Keempat, Melalui media pembelajaran metode media kertas lipat siswa lebih antusias dalam mengikuti kegiatan belajar di ruangan.

Dengan demikian berdasarkan hasil penelitian dari beberpa literasi yang telah dilakukan terbukti bahwa melalui media melalui media pembelajaran metode media kertas melalui kegiatan bermain dapat meningkatkan motorik halus pada anak usia dini.

\section{Simpulan}

Berdasarkan hasil penelitian diatas tentang pembelajaran dengan menggunakan metode media kertas lipat melalui kegiatan bermain untuk meningkatkan motorik halus anak usia dini. Hasil penelitiannya adalah bahwa setiap penelitian yang telah dilakukan dan telah memperoleh hasil persentase yang menunjukan adanya peningkatan hasil belajar siswa PAUD, dapat disimpulkan bahwa: Kode data A1 skor pretes menunjukan data dari $26 \%$ menjadi $34 \% \%$ sehingga peningkatannya $8 \%$. Kode data A2 menunjukan dari 23,5\% menjadi 76,4\% dengan peningkatan mencapai $52,9 \%$. Kode data A3 dari 49,58\% menjadi $82,91 \%$ dengan peningkatan mencapai $25,14 \%$. Rata-rata hasil pencapaian dari ketiga judul yang dianalisis sebelum menggunakam model pembelajaran media lipat kertas yaitu 33,02\%dan sesudah menggunakan media lipat kertas meningkat menjadi $64,43 \%$ dengan ratarata peningkatan $31,41 \%$.

Dari hasil penelitian yang dilakukan peneliti-peneliti sebelumnya bahwa metode pembelajaran dengan 
menggunakan media lipat kertas dapat meningkatkan motorik halus pada anak usia dini, artinya terdapat peningkatan motorik halus pada anak usia dini dengan menggunakan media kertas lipat.

\section{Saran}

Berdasarkan hasil penelitian dengan Pembelajaran dengan menggunakan media kertas lipat melalui kegiatan bermaian untuk meingkatkan motorik halus pada Anak Usia dini diatas, maka peneliti mengajukan beberapa saran diantaranya pertama, Bagi pihak sekolah, disarankan untuk lebih memperhatikan fasilitas dan melakkan koordinasi antar lembaga di lingkungan sekolah karena sangat menunjang bagi perkembangan anak. Kedua, Peneliti selanjutnya yang ingin mengadakan penelitian lebih lanjut tantang metode pembelajaran dengan menggunakan media kertas lipat melalui kegiatan bermaian untuk meingkatkan motorik halus pada Anak Usia dini disarankan untuk lebih mendalami lagi, karena masih banyak hal menarik yang dapat diperoleh dengan menggunakan media pembelajaran ini.

\section{DAFTAR PUSTAKA}

Damay Denidya. (2012). Tips Trik Meningkatkan Ketekunan \& Ketelitian Anak Agar Sukses \& Berprestasi. Yogyakarta :Araska

Diana, Mutiah. (2010). Psikologi Bermain Anak Usia Dini. Jakarta :kencana

Hasnida. (2014). Analisis Kebutuhan Khusus. Jakarta Timur :Luxima

Mansur, Pendidikan Anak Usia Dini dalam Islam (Yogyakarta: Pustaka Pelajar, 2009), Hal. 83-84

Hildayani, (Rini). 2011. Psikologi Perkembangan Anak. Jakarta: Universitas Terbuka
Jamaris, (Martini, 2016). Perkembangan dan Pengembangan Anaki. Jakarta:Grasindo

Latif, Mukhtar. Dkk. (2013). Orientasi Baru Pendidikan Anak Usia. Jakarta : Kencana

Mursid. (2018). Belajar dan Pembelajaran PAUD. Bandung : Remaja Rosdakarya. Hal 64

Nana Syaodih kumadinata. (2017). Metode Penelitian Pendidikan. Remaja sodya karya. Hal 42

Permendiknas RI No. 20 tahun (2003) tentang SistemPendidikan Nasional

Risaldy, Sabil. (2014). Bermain, Bercerita \& Menyanyi Bagi Anak Usia Dini. Jakarta Timur :Luximia Metro Media

Simpleepaper. (2012). Origami, Pengertian dan Manfaat. [internet]. Diunduh 27 Mei 2020. Tersedia pada http://simpleepaper.blogspot.co.id /2012/02/ origami-adalah.html

Suhada, Idad. (2016). Psikologi Perkembangan Anak Usia Dini. Bandung : Remaja Rosdakarya

Sujiono, Bambang. (2017). Metode Pengembangan Fisik. Tangerang Selatan : Universitas Terbuka.

Sumantri, Model Pengembangan Keterampilan Motorik Anak Usia Dini. Jakarta : Depdiknas 2005.

Somadayo, Samsu. (2013). Penelitian Tindakan Kelas. Yogyakarta: Graha

Winarti, Eka Sukma, (2016). Peningkatan Hasil Belajar Siswa dalam Mengidentifikasi Sifat-sifat Bangun Datar Pada Pembelajaran Matematika Menggunakan Media Kertas Lipat, (Skripsi FKIP UNPAS) 